\title{
Ecological Characteristics and Morphological Features of the Lubigi Wetland in Uganda
}

\author{
John K. Kayima, Aloyce W. Mayo", Joel Nobert \\ Department of Water Resources Engineering, University of Dar es Salaam, P.O. Box 35131, Dares Salaam, Tanzania
}

Copyright $(2018$ by authors, all rights reserved. Authors agree that this article remains permanently open access under the terms of the Creative Commons Attribution License 4.0 International License

\begin{abstract}
The Lubigi is one of the largest Lake Kyoga drainage basin wetlands located in the north-western part of Kampala, the capital city of Uganda. It receives stormwater and polluted water from Kampala city and discharges it into Mayanja River and finally Lake Kyoga. Unfortunately, there is lack of information and knowledge on the capacity of the Lubigi wetland to protect the downstream water bodies from pollution. In an effort to address this it was necessary to investigate ecological and morphological characteristics of the Lubigi wetland. Pertinent field investigations, surveys, data collection and field tests and analyses were carried out. The results revealed that the area of drainage basin feeding the wetland is about $40 \mathrm{~km}^{2}$. The width of wetland main study area varies from $250 \mathrm{~m}$ to $450 \mathrm{~m}$ and water depth varies up to a maximum of $2.5 \mathrm{~m}$. The wetland study area has a total surface area and volume are 1.09 ha and 1,073,000 $\mathrm{m}^{3}$, respectively. The wetland soil is dominated by thick loose peat near the inlet, but thickness of loose peat decreased rapidly towards the downstream end. Nine plant species were dominant in Lubigi wetland, but the most dominant species are Echinochloa pyramidalis, Cyperus papyrus, Thelypteris acuminata and Paspalum crobiculatum.
\end{abstract}

Keywords Ecological Characteristics, Lubigi Wetland, Morphological Features, Plant Species, Wetland Capacity

\section{Introduction}

Natural wetlands are characterised by impeded drainage, but vary in detail depending on the period of flooding, depth of water and its fluctuations with time i.e. the hydroperiod, altitude, fertility of the surrounding soil and other environmental factors. They are characterized by having distinctive plants and animals, which live together and are adapted to flooding [1]. The impeded drainage in a natural wetland, allows the water to stay in one place long enough to maximize infiltration, which helps in recharging the groundwater. A high ground water table means that in the immediate surroundings of the wetland, plants have easy access to water supplies [2, 3, 4, 5]. Wetlands also protect the region downstream from erosive forces of storm water flow events, resulting in soil erosion and stream bank degradation.

Natural wetlands are often used for domestic and municipal wastewater disposal and inappropriate and illegitimate solid waste disposal. However, wetlands have capacities to remove pollutants, nutrients and toxins from water, thus to some extent filtering and purifying it $[6,7]$. This function enables natural wetlands to act as "ecotones" acting as buffer zones, which helps to protect the quality of water in downstream fresh water bodies such as rivers and lakes $[8,9,10,11]$.

Natural wetlands cover about $10 \%$ of Uganda's total land surface area, and provide a wide variety of bio-physical and socio-economic functions. The wide distribution of natural wetlands in Uganda, means that a large proportion of the population has access to the utilization of the natural wetlands, resulting in their extensive and intensive degradation in many cases. This demands for particular urgency in their efficient management and sustainable utilization [12].

In Uganda and indeed the whole of the East African region, research work on wetlands, have tended to focus more on the Lake Victoria drainage basin [13, 14, 15, 16, 17]. This is justifiable, because Lake Victoria is the largest inland fresh-water lake in Africa and the second largest in the world, with resources of great socio-economic potential [18]. That notwithstanding, Uganda still has yet another important inland Lake Kyoga drainage basin, which is fed and drained mainly by the River Nile, and its drainage basin is estimated to accommodate about 15 million people, with numerous socio-economic functions. More than $80 \%$ of the population living in the basin, engages in small-scale agriculture and animal husbandry. Thus, the Lake Kyoga drainage basin and its wetlands, including Lubigi wetland, face serious public health, environmental and water 
resources problems [12].

Lubigi wetland has continued to come under severe strain from anthropogenic encroachment and activities including deliberate landfilling for reclamation, human settlements, draining away of water for agriculture and livestock farming, clay and sand extraction, brickmaking, the harvesting of Cyperus papyrus and other plants for handcrafts and house roof thatching, inappropriate and illegitimate solid waste disposal and municipal and industrial effluent discharges [19]. Indeed, in the years 2011 and 2013, serious life threatening conflicts were reported, which forced the Uganda Government security forces to evict people who had constructed buildings in the wetland.

The main water inlet into the Lubigi wetland is a canalised stream, which receives discharges from the newly constructed Nsooba-Lubigi drainage channel with average capacity of approximately $220,000 \mathrm{~m}^{3} /$ day. The channel collects municipal and industrial wastewater, storm water run-off and sub-surface water flow from the upstream densely populated slums of Kyebando, Kalerwe, Kanyanya, Bwaise, Kawaala, Namungoona and Nansana. In addition, the stream receives effluent discharges from Lubigi Sewage Treatment Plant, with a design capacity of $5,400 \mathrm{~m}^{3} /$ day [20].

While it is important to note that wetland morphological features and ecological, characteristics, which play a vital role in determining the capacity of a wetland to transform and remove pollutants from wastewater, very little is known of these features for Lubigi wetland. These characteristics for wetlands have been reported to influence the efficiency of removal of pollutants and improve long-term sustainable management, use and conservation of the wetland $[21,22,23,24]$. Therefore, detailed information about these vital wetland ecological factors also needs to be obtained for the Lubigi wetland. The main objective of this research study is to investigate the morphological features and ecological characteristics of the Lubigi wetland, in order to establish the key wetland morphology and ecological features of the wetland.

\section{Materials and Methods}

\section{The Lubigi Wetland Main Study Area}

The main area investigated in this research study, is as shown in Figure 1. The area comprises the Upper Lubigi wetland, which is delineated in the north-east of Kampala city by the Hoima Road, with the main wastewater inlet located at latitude $00^{\circ} 20^{\prime} 48^{\prime \prime} \mathrm{N}$ and longitude $32^{\circ} 32^{\prime} 28^{\prime \prime} \mathrm{E}$; and in the south-west by the Sentema Road with the main effluent outlets located at latitude $00^{\circ} 19^{\prime} 56^{\prime \prime} \mathrm{N}$ and longitude $32^{\circ} 31^{\prime} 34^{\prime \prime} \mathrm{E}$ (Figure 1). This section of the wetland covers an area of approximately $1.1 \mathrm{~km}^{2}$, at an altitude of approximately $1,158 \mathrm{~m}$ above mean sea level, with a total drainage catchment area of approximately 40.0 $\mathrm{km}^{2}$. This is the section of the wetland, which receives the initial and direct impacts of the visually heavily polluted wastewater from the upstream Nsooba-Lubigi storm water drainage channel and the Lubigi Sewage Treatment Plant. 


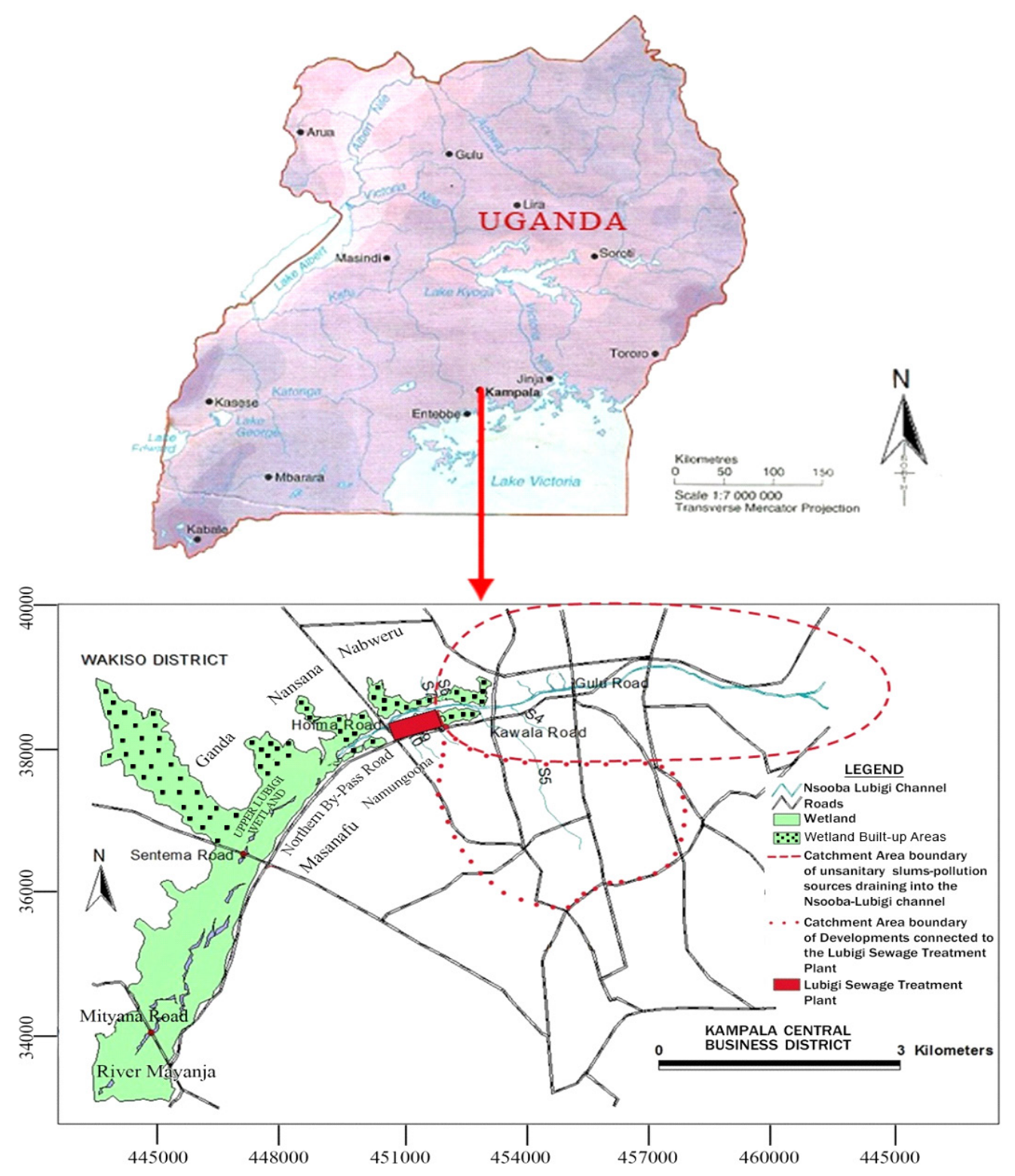

Figure 1. Map of the Lubigi Wetland Main Study Area

In this area, the zone closest to the wetland main wastewater inlet is dominated by Echinochloa pyramidalis, and therefore a $1.0 \mathrm{~m}$ wide transect $\mathrm{T} 1$ was cut across this zone about $700 \mathrm{~m}$ downstream of the main wastewater inlet. The middle zone is dominated by a mix of Cyperus papyrus and Typha capensis, and therefore a second $1.0 \mathrm{~m}$ wide transect T2 was cut across this zone, about 1,440 m downstream of the main wastewater inlet. The last zone closest to the wetland main effluent outlet is dominated by Cyperus papyrus, and therefore a third $1.0 \mathrm{~m}$ wide transect T3 was cut across this zone about $1,930 \mathrm{~m}$ downstream of the main wastewater inlet. Transects T1, T2 and T3 are shown in Figure 1.

In each of the 3 transects, 5 sampling points were established in order to closely follow the spatial variability across the widths of the wetland, as one moves from the main central drainage channel away towards the edges of the wetland on either side of the channel. The transects and sampling points were geo-referenced using a Garmin Global Positioning System (GPS) device, in order to determine and record the co-ordinates of their locations. Then they were transferred to a digitized map of the area, to ensure that the same transects and points are used every time sampling is done. To facilitate movements and work within the transects, Cyperus papyrus culms were cut and tied in bundles which were laid down to make walkable paths. Dinghy boats and motor vehicles were used as alternatives, to access places that were not easily accessible by foot. Life rafts and jackets and other safety precautions and measures, were used throughout the research field work.

\section{Lubigi Wetland Morphology}

A reconnaissance survey followed by a topographic 
survey of the whole study area using a Total Surveying Station and dual frequency $\mathrm{CHCG}$ Global Positioning System (GPS) instruments were conducted, in order to determine the wetland basin geometry, shape, form, size, topography, bathymetry and morphology. The wetland basin morphological features were determined from measurements of the vertical and horizontal cross-sections profiles along the 3 transects T1, T2 and T3, and the longitudinal section, to facilitate the identification of the nature of the basin bottom, and the flow paths, estimation of the effective depths of water flow and therefore the flow cross-sectional areas and measurement of the floating rhizomatous mat thicknesses, free water column depths, loose peat thicknesses and firm sediment levels, using a special profiler rod pushed through holes made through the mat with the aid of a hand auger.

Measurements were made at $50 \mathrm{~m}$ intervals along the 3 transects starting from the Namungoona-Masanafu edge of the wetland, and the levels were related to altitudes above mean sea level. Also measurements were made at $200 \mathrm{~m}$ intervals from the main wetland water inlet to the main outlet, in order to establish and plot the longitudinal section of the wetland. The atmospheric pressure makes the water surface the same in the whole wetland, and thus it was used as a reference datum in conjunction with the nearby established National Ordinance Survey bench marks. All the above surveys, measurements and plotting lead to the determination of the wetland morphology, for subsequent determination of the effectiveness and efficiency of the wetland as a pollutant transformation and removal device/reactor.

The area of the wetland main study section itself and also of its whole upstream catchment drainage area and the floating rhizomatous mat, were determined using ArcGIS 9.3 from field observations and remote sensing of satellite pictures from Google Earth. Thus a Triangulated Irregular Network (TIN) model of the section was developed in conjunction with the topographic and basin depth measurements, and these were used to determine the volume of the wetland main study section, and the volume of the rhizomatous mat. The volume of the free water column below the mat was calculated as the difference between the total volume of the basin of the wetland main study section and the volume of the rhizomatous mat.

The data used to develop bathymetry, was obtained from integrating the bathymetry survey and ASTERGDEM 30 $\mathrm{m}$ resolution optimisation, by removing vegetation and integrating with wetland depth measurements. To manipulate the Triangulated Irregular Network (TIN) model and then determine the required volumes, optimisation of the Triangulated Irregular Network (TIN) model was done. This process involved river burning, filling of sinks, flow accumulation and watercourse drainage system generation $[25,26]$. The process was carried out iteratively, until the defined watercourse drainage system matched the digitised one. Finally, the accuracy of the improved Triangulated Irregular Network
(TIN) model was checked. Thereafter, the area of interest was controlled and its volume was determined by mosaiking the bathymetry grid, the Triangulated Irregular Network (TIN) model and the improved ASTERGDEM2 grid Triangulated Irregular Network (TIN) model.

\section{Lubigi Wetland Topography and Geology}

Hydrometerological data on wetland temperatures, solar radiation, vapour pressure deficits, relative humidities and wind speeds were obtained from the Uganda National Meteorological Authority. Wetland topographic data were obtained from the Uganda Surveys and Mapping Department, and the topographic survey of the wetland main study area using a Total Surveying Station and dual frequency CHCG Global Positioning System (GPS) instruments. Data on the geology, hydrogeology and soils of the wetland area was obtained from literature from the Uganda Geological Survey Department [27], and from in situ measurements of resistivities applying the Wenner 4-point Test. The WDJD-4 low-frequency soil resistivity meter connected to WDZJ-4 soil electrodes was used in this test.

\section{Determination of Plants Species and Dominance}

To determine the existing major vegetation zones in the Lubigi wetland, investigations in the 3 transects T1, T2 and $\mathrm{T} 3$ were conducted. The vegetation zonations by dominant plant communities, were established by ground surveys in the transects. A $1 \mathrm{~m}$ x $1 \mathrm{~m}$ quadrats grid system marked with permanent numbered eucalyptus poles, was used to identify the locations of the major vegetation communities in the wetland. The $1 \mathrm{~m} \times 1 \mathrm{~m}$ quadrats grid system, consisted of 5 sampling quadrats established at a spacing of about $50 \mathrm{~m}$ in each transect. The coordinates and altitudes of each sampling quadrat were recorded using a Garmin Global Positioning System (GPS) device.

From the transect surveys, two major vegetation zones were delineated in the wetland, basing on the types of vegetation observed. These zones were marked and recorded with the use of a Garmin Global Positioning System (GPS) device. The voucher specimens of plant species were collected from the field, assigned collection identities, notes recorded about each of them and sent to the Makerere University Herbarium in Uganda for scientific identification. The authenticity of the scientific names was verified using the African Plant Database.

To determine the vegetation dominance in the identified major vegetation zones, the established $1 \mathrm{~m}$ x $1 \mathrm{~m}$ quadrats grid system was used. Dominant plant species are the most abundant, and exert the most influence or control on the habitat and other plant species [28, 29, 30]. Dominance forms can differ with plant species, and plant species can change their form of dominance over time [31]. Vegetation data were collected from the two major vegetation zones, which represent a random sample of the whole wetland. In each of the two major vegetation zones, the covers of the various plant species rooted in $1 \mathrm{~m} \times 1 \mathrm{~m}$ quadrats were visually assessed. 


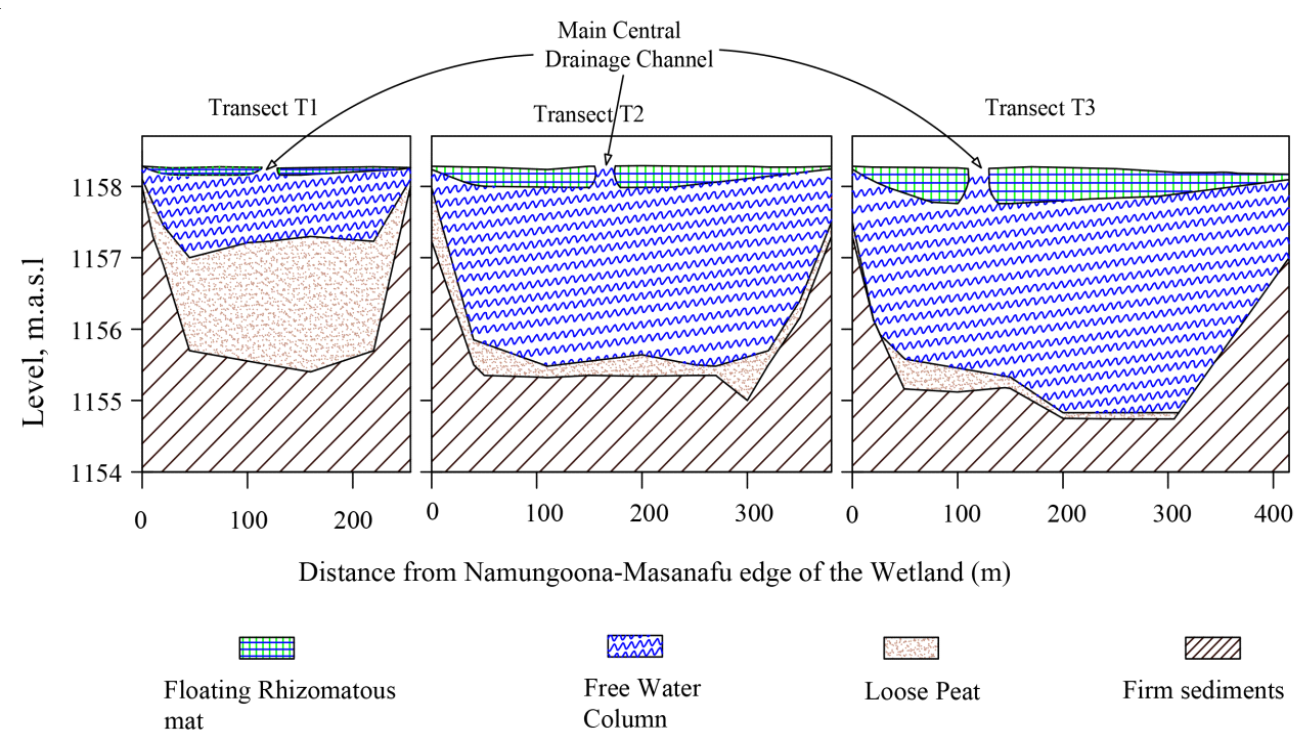

$\underline{\text { Scale: }}$ HS $=1: 6000 \mathrm{~mm}, \mathrm{VS}=1: 90 \mathrm{~mm}(\mathrm{~A} 4)$

Figure 2. Typical Cross-sections Along Transects T1, T2 and T3.

\section{Results and Discussion}

\section{Wetland Morphology}

The Lubigi is a tropical, natural, perennial, shallow and drowned-valley wetland. It is rheotrophic i.e fed principally by surface water systems, pulstrine and colonized by various species of wetland macrophytes. The Lubigi wetland main study area is bounded on the north-western side by the Nansana and Ganda towns, and on the south-eastern side by the Namungoona and Masanafu towns as shown in Figure 1. The width of the wetland main study area, varies between $250 \mathrm{~m}$ and $450 \mathrm{~m}$. Typical measurements and cross-sections along the transects $\mathrm{T} 1, \mathrm{~T} 2$ and $\mathrm{T} 3$, during the rainy season in September 2016 are presented in Figure 2.

The zone closest to the wetland main water inlet, has shallow water depths overlying thick layers of loose peat. Further downstream towards the effluent outlets, the free water column depths and the floating rhizomatous mat thicknesses increase, while the peat layers become thinner. These observations can be attributed to the following factors:

- The floating rhizotomous mat thicknesses increasing towards the effluent outlets, due to the considerable increases in plants densities as one moves from the main water inlet to the effluent outlets; and also the markedly increasing dominance and densities of Cyperus Papyrus, a highly productive macrophyte with rhizomatic interweaving roots structures forming the bulk of the floating mat, as one moves from the main water inlet to the effluent outlets.

- The free water columns growing deeper towards the effluent outlets, due to the progressively accumulating total water outflux, as the water influx components like influent discharges, storm water run-off, sub-surface flow and rainfall keep contributing water to the wetland basin. In addition, as water exits the Lubigi wetland main study area through culverts under the Sentema road, the road exerts a damming effect on the water

- Loose peat thicknesses decreasing towards the effluent outlets, because when allochthonous waters enter into the wetland, flow velocities keep decreasing and thus the heavy suspended solids tend to be deposited between the main water inlet and transect $\mathrm{T} 1$, the lighter/finer materials remaining tend to be deposited with increasing difficulty between transect $\mathrm{T} 1$ and transect $\mathrm{T} 2$, and the remaining lightest/finest materials are hardly deposited at all between transect $\mathrm{T} 2$ and the effluent outlets.

These resultant cross-section profiles as depicted in Figure 2 have profound impacts on the velocities of water flowing through the wetland, because they affect the cross-sectional areas of the wetland and the resistances to water flow. These in turn have impacts on the wetland hydraulic residence times, and thus the times pollutants spend in contact with the various components of the wetland ecological environment. These also in turn have direct and profound impacts on the capacity of the wetland, to support the biogeochemical mechanisms and processes governing the transformation and removal of pollutants in the wetland. In addition, the loose hanging roots of the floating rhizomatous mat, increase the surface area for the plant uptake of nitrogen and other nutrients, and the attachment of biofilms, the transformation and removal of nitrogen and bacteria [32].

There is a visibly prominent main central drainage channel in the wetland, running from the wetland main 
water inlet at the Hoima Road, to the effluent outlets on the Sentema Road. There are also large open water ponds just upstream of the Sentema Road. In general, the Lubigi wetland exhibits a gentle tilting from its Nansana-Ganda edge towards its Namungoona-Masanafu edge, of approximately $0.15 \%$. This tilt causes the wetland's main central drainage channel to gradually curve from the Nansana-Ganda edge towards the Namungoona-Masanafu edge, as the channel slopes from the main wetland water inlet at the Hoima Road, to the main effluent outlets at the Sentema Road. Water depths vary from approximately 0.1 $\mathrm{m}$ at the edges of the wetland to approximately $1.0 \mathrm{~m}$ and $3.0 \mathrm{~m}$ in the main central drainage channel, during the dry seasons and the rainy seasons, respectively.

Figure 3, show the measurements of the relative vertical distributions of the floating rhizomatous mat, free water column, loose peat and firm sediments as one moves from the main wetland water inlet to the main effluent outlets, and the resultant typical longitudinal section. It is clearly evident that the zone closest to the wetland main water inlet having shallow water depths overlying thick layers of loose peat. Further downstream towards the effluent outlets, the free water column depths and the floating rhizomatous mat thicknesses increase, while the peat layers become thinner. The wetland has longitudinal slopes from the main inlet toward $\mathrm{T} 1$ of approximately $0.03 \%, \mathrm{~T} 1$ to $\mathrm{T} 2$ of approximately $0.22 \%$ and $\mathrm{T} 2$ to the outlets of about $0.16 \%$.

In the wetland, the rooted emergent vegetation at the edges, gradually transforms into a floating rhizomatous mat zone in the middle of the wetland. The undisturbed portions of the wetland are bordered by rooted vegetation, inundated by storm water run-off. During the dry seasons (June to September and November to March), the floating rhizomatous mat was almost attached to the bottom of the wetland basin, and the plants tended to appear yellowish in approximately $30 \%$ of the wetland. However, during the subsequent rainy seasons (March to June and September to November), it was observed that the increased water flow lifted the floating rhizomatous mat up, and the plants turned green.

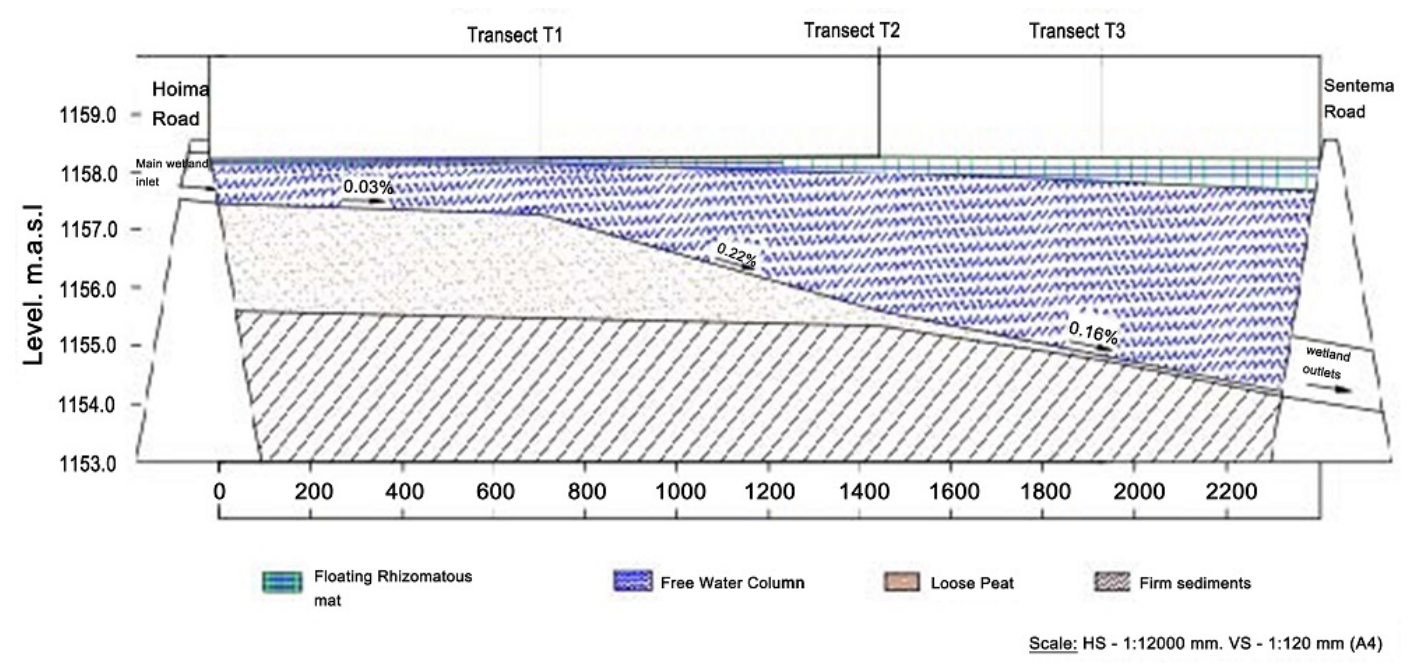

Figure 3. Lubigi Wetland Typical Longitudinal Section, cross-section

Table 1. Lubigi Wetland Resistivities, Geology and Soils

\begin{tabular}{|c|c|c|c|c|c|c|c|}
\hline \multicolumn{2}{|c|}{ Location } & \multicolumn{3}{c|}{ Namugoona-Masanafu edge } & \multicolumn{3}{c|}{ Nansana-Ganda edge } \\
\hline \multicolumn{2}{|c|}{ Transect } & $\mathrm{T} 1$ & $\mathrm{~T} 2$ & $\mathrm{~T} 3$ & $\mathrm{~T} 1$ & $\mathrm{~T} 2$ & $\mathrm{~T} 3$ \\
\hline \multirow{2}{*}{$\begin{array}{c}\text { Weathered } \\
\text { laterites }\end{array}$} & $\mathrm{D}(\mathrm{m})$ & $0-1.0$ & $0-0.9$ & $0-1.3$ & $0-1.2$ & $0-1.1$ & $0-0.8$ \\
\cline { 2 - 8 } & $\mathrm{k}(\Omega \mathrm{m})$ & 100.0 & 200.0 & 200.0 & 150.0 & 100.0 & 100.0 \\
\hline \multirow{3}{*}{ Sands and Silts } & $\mathrm{D}(\mathrm{m})$ & $1-1.5$ & $0.9-1.4$ & $1.3-1.8$ & $1.2-1.7$ & $1.1-1.4$ & $0.8-1.3$ \\
\cline { 2 - 8 } & $\mathrm{k}(\Omega \mathrm{m})$ & 50 & 40 & 40 & 30 & 50 & 30 \\
\hline \multirow{2}{*}{ Clays } & $\mathrm{D}(\mathrm{m})$ & $1.5-21.5$ & $1.4-25.3$ & $1.8-29.8$ & $1.7-23.6$ & $1.4-27.4$ & $1.3-34.3$ \\
\cline { 2 - 8 } & $\mathrm{K}(\Omega \mathrm{m})$ & 30 & 20 & 10 & 10 & 15 & 20 \\
\hline \multirow{2}{*}{$\begin{array}{c}\text { Weathered } \\
\text { rocks }\end{array}$} & $\mathrm{D}(\mathrm{m})$ & $21.5-51.5$ & $25.3-55.6$ & $29.8-57.7$ & $23.6-53.8$ & $27.4-56.0$ & $34.3-58.3$ \\
\cline { 2 - 8 } & $\mathrm{k}(\Omega \mathrm{m})$ & 80.0 & 100.0 & 150.0 & 150.0 & 200.0 & 100.0 \\
\hline \multirow{2}{*}{$\begin{array}{c}\text { Granites \& } \\
\text { Gneisses }\end{array}$} & $\mathrm{D}(\mathrm{m})$ & $>51.5$ & $>55.6$ & $>57.7$ & $>53.8$ & $>56.0$ & $>58.3$ \\
\cline { 2 - 8 } & $\mathrm{k}(\Omega \mathrm{m})$ & $1 \times 10^{3}$ & $1 \times 10^{4}$ & $1 \times 10^{3}$ & $1 \times 10^{5}$ & $1 \times 10^{4}$ & $1 \times 10^{5}$ \\
\hline
\end{tabular}

$\mathrm{D}=$ Depth below ground surface in $\mathrm{m}$; $\mathrm{k}=$ Resistivity in ohm-m 


\section{Characteristics of Lubigi Wetland}

The Lubigi wetland experiences a typical tropical, moist, sub-humid and bi-seasonal rainfall climate, receiving rain during two rainy seasons, in March to June and September to November of each year. However, even during the drier months, occasional heavy rains do occur. Short-duration thunderstorms accompanied by flash floods are particularly common in this area. The mean annual rainfall amounts to $1,450 \pm 239 \mathrm{~mm}$. The mean daily temperature ranges from $15^{\circ} \mathrm{C}$ to $30^{\circ} \mathrm{C}$. The mean annual solar radiation is $529.1 \pm 86.4 \mathrm{cal} / \mathrm{m}^{2} / \mathrm{d}$. The mean annual vapour pressure deficit is $165.7 \pm 32.4 \mathrm{Kpa}$. The mean annual relative humidity is $81.7 \pm 4.0 \%$ and the mean annual wind speed is $1.126 \pm 0.524 \mathrm{~m} / \mathrm{s}$ [33]. The drainage catchment area of the wetland has a gently sloping topography of approximately $1 \mathrm{~m}$ in 45,000 $\mathrm{m}$ towards the wetland basin. The geology, hydrogeology and soils results of the Lubigi wetland area as presented in Table 1 and Figure 4.

Table 1 shows that at all the points surveyed in the Lubigi wetland area, the layer of top weathered laterites from $0.0 \mathrm{~m}$ to $1.3 \mathrm{~m}$ depth below ground surface, is underlain by layers of sands and silts varying between 0.3 to $0.5 \mathrm{~m}$ thick. The sands and silts are underlain by a very low resistivity clay aquiclude ranging from $20.0 \mathrm{~m}$ to 33.0 $\mathrm{m}$ thick. From observations in the boreholes augered along the edges of the wetland, layers of latarites, sand and silts overlaying clay were encountered in the top $1.0 \mathrm{~m}$ to $2.0 \mathrm{~m}$. Where the soils allowed for deeper boring, thick, stiff and compact clays were encountered within depths of $2.0 \mathrm{~m}$ to $3.0 \mathrm{~m}$. This further confirms that the contribution of ground water fluxes into the wetland water body via seepage, and the loss of water from the water body via infiltration through the soils down into the rocks, are insignificant and negligible for the water balance considerations.

Figure 5 presents the Triangulated Irregular Network (TIN) model, of the Lubigi wetland main study area. The Triangulated Irregular Network model (TIN) was developed to show the relief features, and the major water flow paths within the entire catchment drainage area of the wetland main study area. In Figure 5, arrows represent the directions of water flow from the upstream areas, to the downstream areas.

From the Triangulated Irregular Network (TIN) model, the total surface area and volume of Lubigi wetland main study area were computed to $1,093,739 \mathrm{~m}^{2}$ and $1,073,056$ $\mathrm{m}^{3}$, respectively. These are key essential inputs into the pollutant mathematical models. The surface area of the whole upstream drainage catchment area of the wetland main study area, was computed to be approximately $39,997,550 \mathrm{~m}^{2}$. It was noted that the wetland main study area is connected to upstream and downstream ecosystems, and laterally characterised by a complex network of inflows from its drainage catchment area, which influence the hydrology and water quality dynamics of the wetland. As a result, this rheotrophic wetland is potentially vulnerable to widespread landscape changes, due to anthropogenic pressures. The observed degradation of the vegetation on the wetland basin valley sides, which act as buffer zone areas, is particularly detrimental, since it exposes the wetland to increased storm water run-off and erosion, with potentially severe consequences for wetland soil stability, hydrology and water quality.
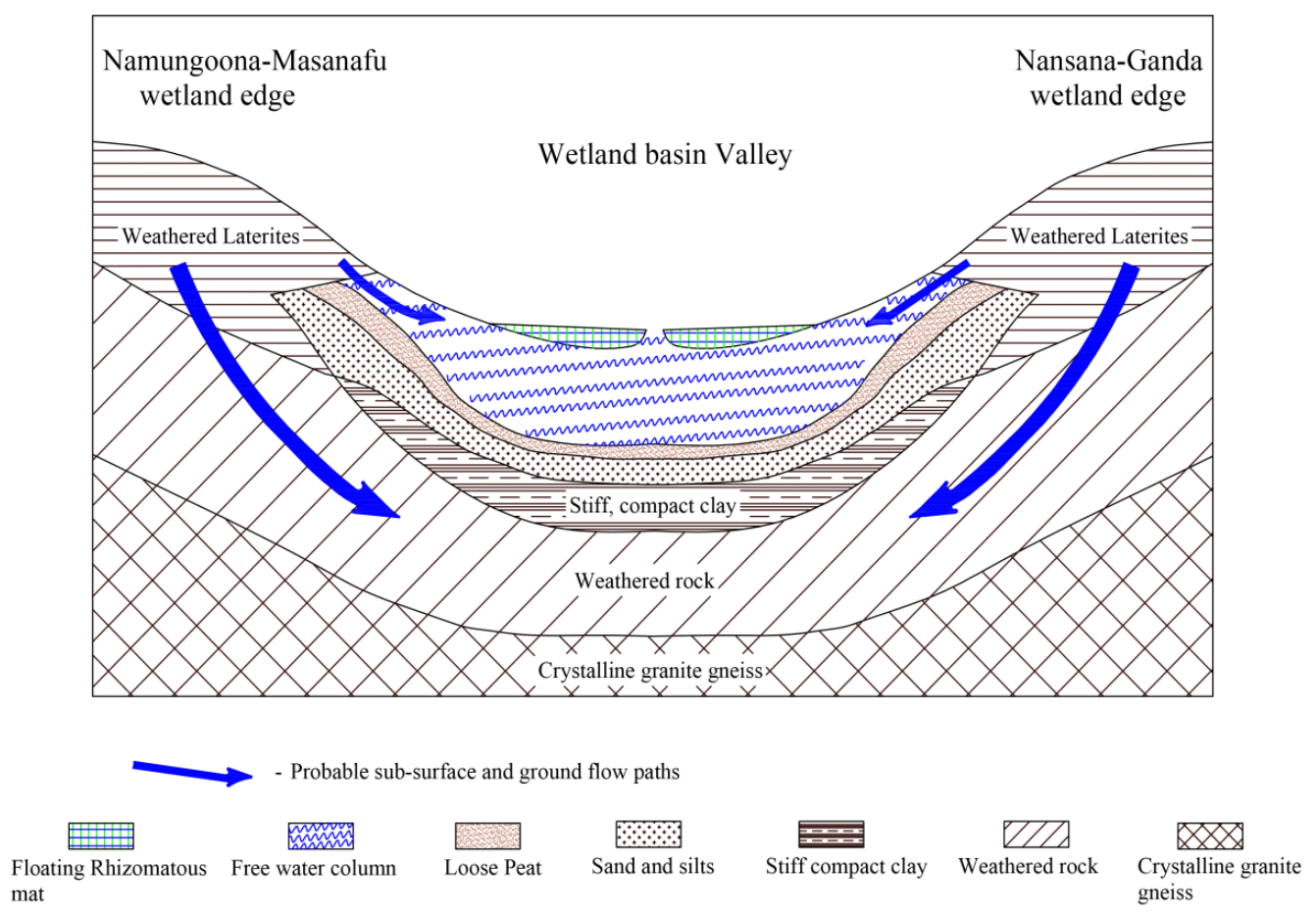

Figure 4. Lubigi wetland typical geological and hydrogeological 


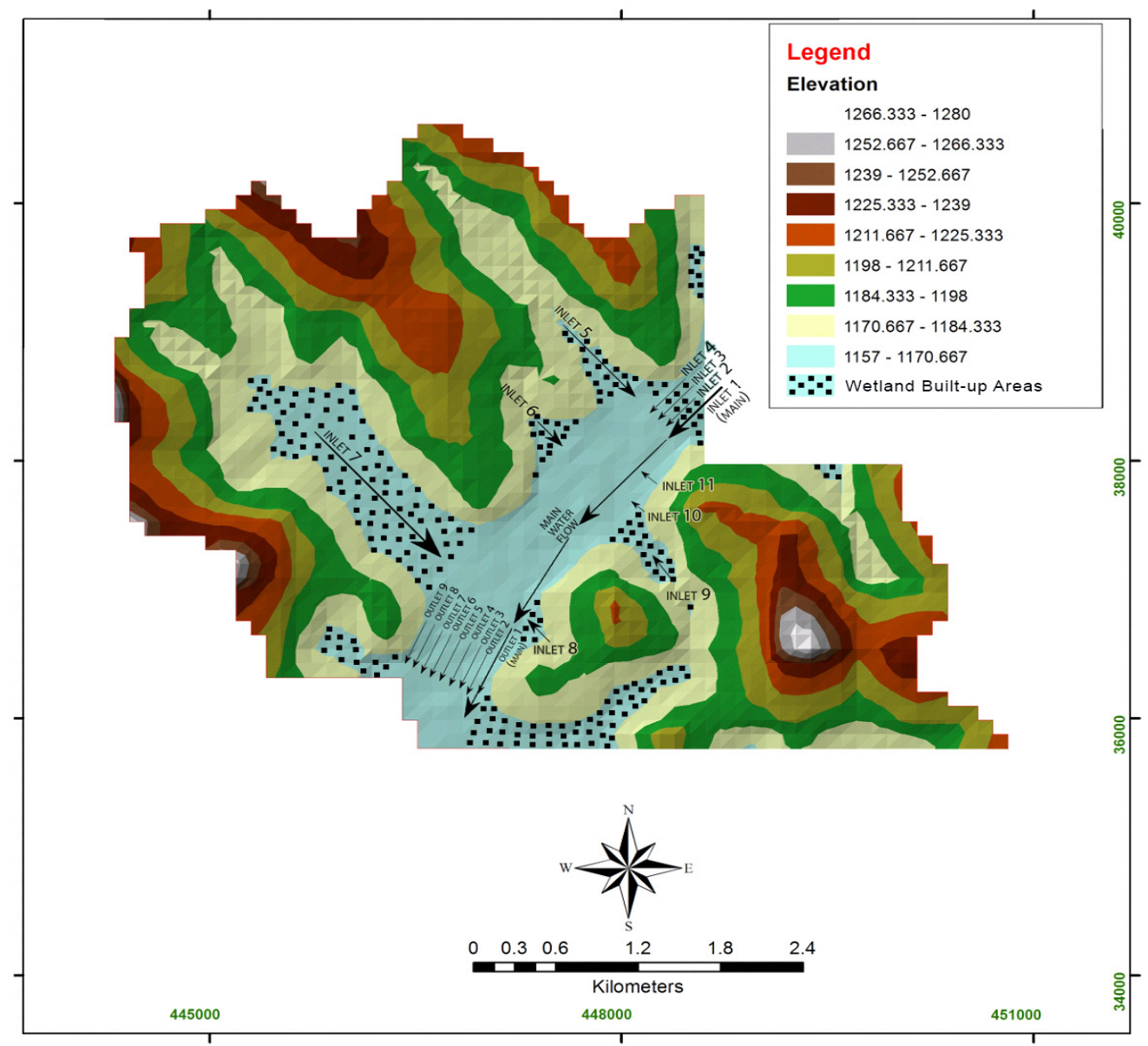

Figure 5. The Lubigi Wetland Triangulated Irregular Network (TIN) Model.

Based on pertinent comparisons of findings from earlier studies of other tropical natural wetlands [34, 35, 36, 37], the Lubigi wetland climatic, meteorological, topographic, geological and hydrogeological characteristics present an environment conducive to biogeochemical mechanisms and processes which mediate the transformation and removal of pollutants.

\section{Wetland flora and fauna}

Figure 6 shows that 9 species are dominant in Lubigi wetland, but the most dominant species are Echinochloa pyramidalis, Cyperus papyrus, Thelypteris acuminata and Paspalum crobiculatum. Four speies exhibited the monotype form of dominance, 1 is ubiquitous, 3 exhibit the compressed form of dominance, 6 are aberrant, 2 are diffuse and one is patchy. Aberrant, monotype and compressed, are the most common forms of dominance in the 3 transects T1, T2 and T3. There was no specie which exhibited the matrix form of dominance. Three dominant species showed only one form of dominance, while the rest showed two forms. Echinochloa pyramidalis was observed to proliferate mainly in the wetland main water inlet zone, and also along the wetland main central drainage channel.

The plants species encountered in the Lubigi wetland, are largely native wetland species, without colonising woody and/or early successional plants species. This would suggest that the wetland has a relatively stable vegetal cover. However, though not encountered in transects $\mathrm{T} 1$, T2 and T3, there was observed along the Namungoona-Masanafu edge of the wetland, an emergence of non-native plant species, which could distort the vegetal composition of the wetland as time goes on.

Lubigi wetland is also a biodiversity havens, acting as breeding grounds and habitat for aquatic animals including birds, fish such as mudfish and lungfish, which can survive in polluted waters. Lubigi wetland supports the lives of small animals like frogs, snakes and about 200 species of birds including the Uganda national bird, the crested crane. However, in recent years wildlife population have been threatened by degradation of the wetland following construction of Lubigi sewerage treatment plant, which was designed to treat $5400 \mathrm{~m}^{3} / \mathrm{d}$ effluent into the Lubigi wetland [38]. The construction of Kampala northern bypass highway and $132 \mathrm{kv}$ high tension electric cables, which pass through the wetland have also further disturbed the natural wildlife habitat [39]. In accordance with Abigaba [40] and Habonimana [41] Lubigi wetland has been degraded by over $40 \%$, which is considerably threatening natural habitat of wildlife in the wetland, particularly birds. 


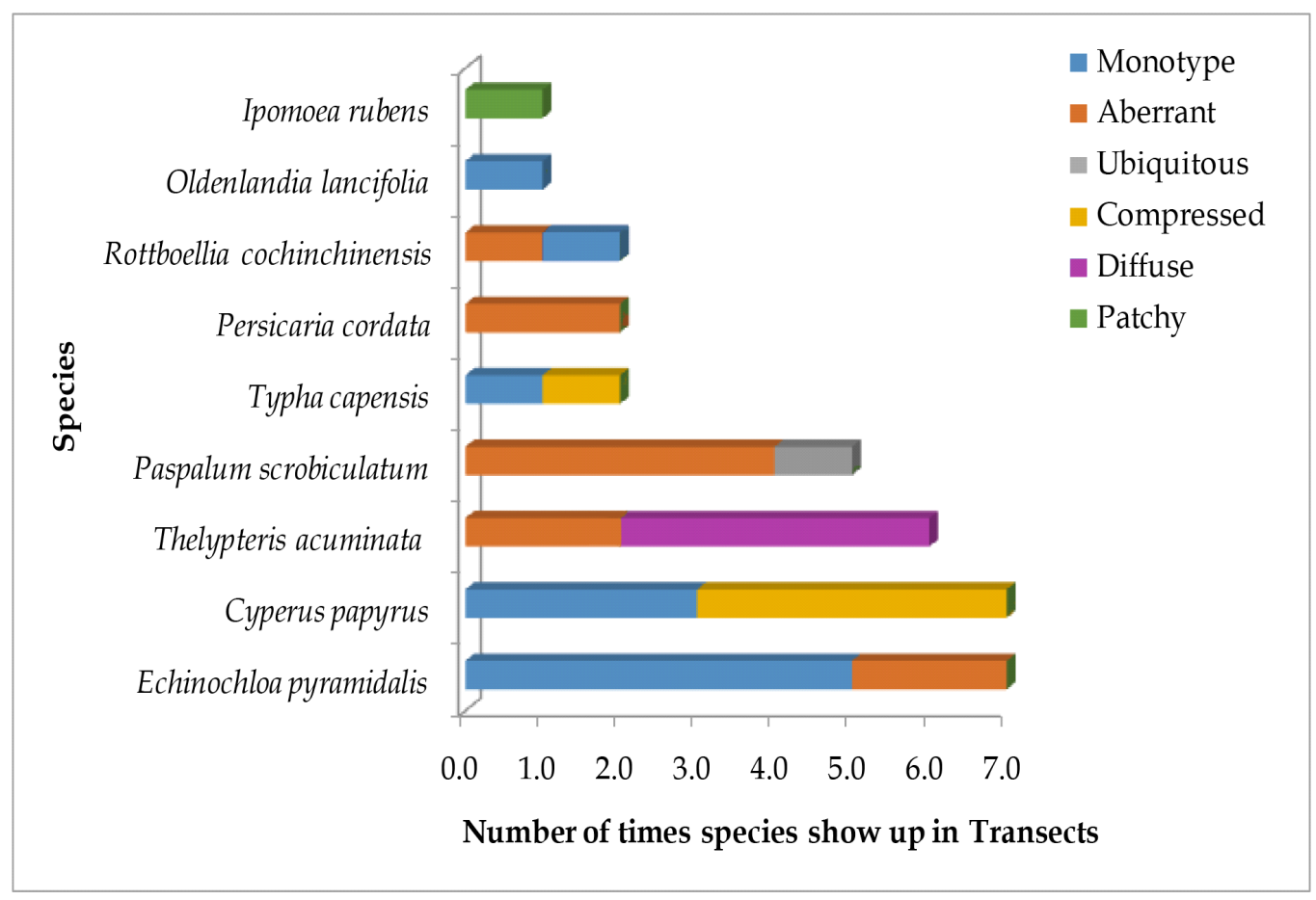

Figure 6. Dominant plant species in the wetland

In Nakivubo and Kirinya wetlands at the shores of Lake Victoria in Uganda, Mugisha et al. [42] reported that the dominant plants were Cyeprus papyrus, Miscanthus violaceus, Phragmites mauritianus and Colocasia $C$. esculenta. In Mara River wetland upstream of Lake Victoria, across the border in Tanzania, Muraza et al. [23] reported that the dominant plant species were Cyperus papyrus, Typha domingesis and Phragmites australis. Other species include Thelpteris interrupta, Echnocloa pyramidalis, Cyperus articulatus, Chara spp., Eichhornia crassipes and Azola spp. Some of these species are uncommon in Lubigi wetland although Cyperus spp, appear in all wetlands around the region.

\section{Conclusions}

The Lubigi wetland morphological features, have direct and profound impacts on the capacity of the wetland to support the biogeochemical mechanisms and processes, governing the transformation and removal of pollutants in the wetland. The Lubigi is a tropical, natural, perennial, shallow and drowned-valley wetland. As a result, the wetland is potentially vulnerable to widespread landscape changes, due to anthropogenic pressures. The observed degradation of the vegetation on the wetland basin valley sides, which act as buffer zone areas, is particularly detrimental because it exposes the wetland to increased storm water run-off and erosion, with potentially severe consequences for wetland soil stability, hydrology and water quality. The Lubigi wetland main study area basin total surface area and volume are approximately $1.09 \mathrm{~km}^{2}$ and 1.07 million $\mathrm{m}^{3}$. The drainage basin upstream of the study area is about $40 \mathrm{~km}^{2}$. The wetland soil is dominated by thick loose peat near the inlet, but thickness of loose peat decreased rapidly towards the downstream end. Nine plant species were dominant in Lubigi wetland, but the most dominant species are Echinochloa pyramidalis, Cyperus papyrus, Thelypteris acuminata and Paspalum crobiculatum. Echinochloa pyramidalis was particularly dorminant near the wetland main water inlet zone, and also along the wetland main central drainage channel.

\section{REFERENCES}

[1] Mitsch W.J. and Gosselink J.G. (2007). Wetlands (Fourth Edition). John Wiley and Sons Inc., Hoboken.

[2] CEC (1995). Wise Use and Conservation of Wetlands. Communication from the Commission to the Council and European Parliament, Commission of the European Communities, Com (95), 189, 154.

[3] Dugan P.J. (1990). Wetland Conservation: A Review of Current Issues and Required Actions. IUNC, Gland, Switzerland.

[4] Maltby E. (1990). Waterlogged Wealth: Why Waste the World's Wet Places?. Earth Science Press, London, U.K.

[5] Hogan D.V., Maltby E., Lloyd J.W. and Baker C.J. (1992). Water Resources Management and the Protection of the Wetland Functioning, NRA: Research and Development Priorities. NRA, Wessex Region.

[6] Mayo, A.W. and Bigambo T. (2005). Nitrogen 
Transformation in Horizontal Subsurface Flow Constructed Wetlands I: Model Development. Journal of Physics and Chemistry of the Earth, 30: 658-667.

[7] Kansiime F. (2004). Functioning and Dynamics of Wetland Vegetation of Lake Victoria. In: Ecotools. Tools for Wetland Ecosystem Resource Management in Eastern Africa. EC RTD INCO-DEV Programme, 5-11.

[8] Allinson G., Stagnitti F., Salzman S., Hill R.J., Cordell S. and Smith L. (2000). Strategies for the Sustainable Management of Industrial Wastewater: Determination of the Chemical Dynamics of a Cascade Series of Five Newly Constructed Ponds. Physics and Chemistry of the Earth, $\mathrm{B}(25)$ : 629-634.

[9] Terer T., Gichuki N.N. and Ndiritu G.G. (2005). Role of Wetlands in Maintaining Stability of Tropical Lakes: A Case Study of River Nyando Delta in Lake Victoria Basin, Kenya. In: Odada, O., Olago, D.O., Ochola, W., Ntiba, M., Wandiga, S., Gichuki, N., Oyieke, H. (Eds.). Proceedings of the $11^{\text {th }}$ World Lakes Conference, Nairobi, Kenya, 560-567.

[10] Henry L. and Semili P. (2005). Levels of heavy metal pollution in water and sediments in Simiyu wetland of Lake Victoria basin (Tanzania). In: Odada O., Olago D.O., Ochola W., Ntiba M., Wandiga S., Gichuki N., Oyieke H. (Eds.). Proceedings of the $11^{\text {th }}$ World Lakes Conference, Nairobi, Kenya, 549-553.

[11] Marwa A. (2013). Treatment of Acid Mine Drainage from North Mara Mine Using Constructed Wetlands. MSc (Eng) Thesis, Department of Chemical and Mining Engineering, University of Dar es Salaam, Tanzania.

[12] Ministry of Water and Environment, Uganda (2015). National Policy for the Conservation and Management of Wetland Resources. Kampala, Uganda.

[13] Balirwa J.S. (1998). Lake Victoria Wetlands and Ecology of the Nile Tilapia, Oreochromis Niloticus Linne. A.A. Balkema Publishers, Rotterdam, The Netherlands.

[14] Muyodi F.J. (2000). Microbiological Analysis of the Waters of Lake Victoria in Relation to the Invasion of the Water Hyacinth, Eichhornia Crassipes (MART.) SOLMS. A Case Study of the Lake Shores of Mwanza Municipality. PhD Thesis, University of Dar es Salaam, Tanzania.

[15] Kipkemboi J., Van Dam A.A., Mathooko J.M. and Denny P. (2007). Hydrology and the Functioning of Seasonal Wetland Aquaculture-agriculture Systems (Fingerponds) at the Shores of Lake Victoria, Kenya. Ecological Engineering, $16,545-560$.

[16] Mayo A.W., Muraza M. and Norbert J. (2014). The Role of Mara River Basin Wetland in Reduction of Nitrogen Load to Lake Victoria. International Journal of Water Resources and Environmental Engineering, 5(12): 659 669.

[17] Mayo A.W., Muraza M. and Norbert J. (2018). Modelling Nitrogen Transformation and Removal in Mara Basin Wetland Upstream of Lake Victoria, Physics and Chemistry of the Earth, March 2018, https://doi.org/10.1016/j.pce.201 8.03.005

[18] Co'zar A. (2007). Relationships between Wetland Ecotones and Inshore Water Quality in the Ugandan Coast of Lake Victoria. Wetlands Ecology and Management, 15: 499-507.

[19] African Development Fund (2008). Uganda: Kampala
Sanitation Programme. Environmental and Social Impact Assessment Summary, Kampala, Uganda.

[20] National Water and Sewerage Corporation (2015). National Water and Sewerage Corporation Sewer Services. Kampala, Uganda.

[21] Terer T., Triest L. and Muasya A.M. (2012). Effects of Harvesting Cyperus papyrus in Undisturbed Wetland, Lake Naivasha, Kenya. Hydrobiologia, 680: 135-148.

[22] Muraza M. (2013). Modelling Nitrogen Transformation and Removal in Mara River Basin Wetlands. MSc Dissertation, Department of Water Resources Engineering, University of Dar es Salaam, Tanzania.

[23] Muraza M., Mayo A.W. and Nobert J. (2013). Wetland Plant Dominance, Density and Biomass in Mara River Basin Wetland Upstream of Lake Victoria in Tanzania. International Journal of Scientific and Technology Research, 2(12): 348-359.

[24] Mburu N., Tebitendwa S., Rousseau D., van Bruggen J. and Lens P. (2013). Performance Evaluation of Horizontal Subsurface Flow-Constructed Wetlands for the Treatment of Domestic Wastewater in the Tropics. Journal of Environmental Engineering, 139: 358-367.

[25] Maidment D.R. and Djokc D. (2000). Hydrologic and Hydraulic Modelling Support with GIS. ESRI, Redland, California, U.S.A.

[26] Maidment D.R. (2002). Arc Hydro, GIS for Water Resources. ESRI, Redlands, California, U.S.A.

[27] Uganda Geological Survey Department (1957). Geological Survey of Uganda. Kampala, Uganda.

[28] Carpenter J.R. (1956). An Ecological Glossary. Hafner Publishing Company, New York, USA.

[29] Greig-Smith P. (1986). Chaos or Order: Organization. In: Kikkawa, J., Anderson, D.J. (eds.), Community Ecology, Melbourne, Australia, Pattern and Process. Blackwell Scientific Publications, 19-29.

[30] Ricklefs R.E. and Miller G.L. (1990). Ecology. W.H. Freeman and Company, New York, U.S.A.

[31] Frieswyk C.B., Johnston C. and Zedler J.B. (2007). Quantifying and qualifying dominance in vegetation Journal of Great Lakes Research, 33(Special Issue 3): 125-135.

[32] Kansiime F., Oryem-Origa H. and Rukwago S. (2005). Comparative Assessment of the Value of Papyrus and Cocoyams for the Restoration of the Nakivubo Wetland in Kampala, Uganda. Physics and Chemistry of the Earth, 30(11-16): 698-705.

[33] Uganda National Meteorological Authority (2016). Uganda Meteorological Data. Kampala, Uganda.

[34] Kansiime F. and Nalubega M. (1999). Wastewater Treatment by a Natural Wetland: The Nakivubo Swamp, Uganda. A. A. Balkema, Rotterdam, The Netherlands.

[35] McJannet D.L. (2007). Towards an Understanding of the Filter Function of Tropical Wetlands: Lessons from Temperate Locations, Development of a Conceptual Model and Design of a Field Monitoring Strategy. CSIRO: Water 
for a Healthy Country National Research Flagship.

[36] Bavor H.J. and Waters M.T. (2008). Buffering Performance in a Papyrus Dominated Wetland System of the Kenyan Portion of the Lake Victoria Basin. In: Vymazal, J. (ed.); Wastewater Treatment, Plant Dynamics and Management in Constructed and Natural Wetlands. Proceedings of the $6^{\text {th }}$ Workshop on Nutrient Cycling in Natural and Constructed Wetlands, Trebon, Czech Republic, Springer, Dordrecht, $33-38$.

[37] Bateganya N.L. (2010). Hydrological and Water Quality Characterisation of a Tropical Riverine Wetland: Nabajjuzi, Uganda, East Africa. MSc. Dissertation, UNESCO-IHE Institute for Water Education, The Netherlands.

[38] Bwambale T. (2014). Museveni commissions sh 53 b Lubigi plant. New Vision. Available online at https://www.newvision.co.ug/new vision/news/1339156/ museveni-commissions-sh53b-lubigi-plant. Retrieved on $9^{\text {th }}$ June 2018.

[39] Kayima J.K. (2018). The fate of nitrogen and faecal coliforms in the Lubigi wetland in Uganda. PhD Thesis submitted for examination. Department of Water Resources Engineering, University of Dar es Salaam.

[40] Abigaba Z. (2010). Lubigi wetland faces extinction. Daily Monitor. Available online at http://www.monitor.co.ug/Ne ws/National/-/688334/907322/-/wy0r8c/-/index.html. Retrieved on $9^{\text {th }}$ June 2018.

[41] Habonimana H.V. (2014). Integrated flood modelling in Lubigi catchment, Kampala. MSc Dissertation, University of Twente, Enschede, The Netherlands.

[42] Mugisha, P.; Kansiime, F.; Mucunguzi, P.; Kateyo, E. (2007). Wetland vegetation and nutrient retention in Nakivubo and Kirinya wetlands in the Lake Victoria basin of Uganda. Physics and Chemistry of the Earth, 32(15-18,): 1359-1365. DOI: 10.1016/j.pce.2007.07.040. 